\title{
KONSEP RASIONALISME RENE DESCARTES DAN RELEVASINYA DALAM PENGEMBANGAN ILMU DAKWAH
}

\author{
Agus Riyadi, Helena Vidya Sukma \\ Fakultas Dakwah dan Komunikasi \\ UIN Walisongo Semarang \\ Jln. Prof. Dr. Hamka, Ngaliyan, Semarang \\ agus.riyadi@walisongo.ac.id, helenavidya@gmail.com
}

\begin{abstract}
Descartes proclaimed that only reason or ratio could be the only reliable basis, and not faith or revelation as always held by medieval times. Apart from that method of doubt, Descartes traced his philosophical thinking by doubting everything in an effort to achieve the ultimate certainty he always missed. Although in the end he realized that there really wasn't anything right, except uncertainty itself. The revelation of Descartes' thinking on the problem of ergo sum is seen as not inherent in the science of da'wah, which is still limited by the truth of the naqli argument. The thought of Descartes which is considered relevant to the science of da'wah lies in the theory of knowledge developed, of course by using the scientific methodology flow. The challenge of proving the truth of Islamic teachings in the field of da'wah is a necessity.
\end{abstract}

Keywords: Rationalism Development, Da'wah.

\begin{abstract}
Abstrak
Descartes memproklamirkan bahwa hanya akal atau rasio sajalah yang dapat menjadi satu-satunya dasar yang dapat dipercaya, dan bukan iman atau wahyu sebagaimana yang selalu dipegangi oleh abad pertengahan. Selain itu metode keraguannya, Descartes menapaki pemikiran filosofisnya dengan menyangsikan segala sesuatu dalam upaya mencapai suatu kepastian hakiki yang selalu ia rindukan. Meskipun pada akhirnya ia menyadari bahwa sesungguhnya tidak ada sesuatu yang benar, kecuali ketidakpastian itu sendiri. Revelansi pemikiran Descartes dalam persoalan cogitu ergo sum dipandang tidak inheren dengan keilmuan dakwah, yang masih terbatasi dengan kebenaran dalil naqli. Pemikiran Descartes yang dianggap relevan dengan keilmuan dakwah terletak pada teori pengetahuan yang dikembangkan, tentunya dengan menggunakan alur metodologi ilmiah. Tantangan untuk membuktikan kebenaran ajaran Islam dalam kancah ilmu dakwah merupakan sebuah keniscayaan.
\end{abstract}

Kata Kunci: Rasionalisme, Pengembangan, Ilmu Dakwah 


\section{A. PENDAHULUAN}

Manusia merupakan sosok yang menginginkan kesempurnaan dalam kehidupannya. Ibnu Khaldun menyatakan bahwa hal ini adalah sunnatullah. Sebagai ciptaan Allah SWT yang sempurna (QS : AlTin 4), manusia selalu mencari kebenaran untuk menjawab keingintahuannya (curiosity). Manusia memaksimalkan akal yang dimilikinya untuk menemukan jawaban atas persoalan yang dihadapinya. Dengan indera yang dimilikinya, manusia mencari dan mendapatkan hal baru yang memang ingin diketahuinya tersebut.

Langkah mencari kebenaran
ini didapatkan dalam kajian filsafat sebagai sebuah cara untuk mendapatkan kebenaran. Dengan perbedaan pengalaman masing-masing orang, seringkali terdapat perbedaan persepsi terkait dengan kebenaran. Persoalannya adalah apakah sesuatu yang selama ini dianggap sebagai sebuah kebenaran dapat dipastikan bahwa hal tersebut mempunyai hakikat kebenaran sebenar-benarnya? Mungkinkah sebuah kebenaran pribadi akan sama dengan pengalaman orang lain? Mengapa klaim kebenaran selalu muncul dalam persepsi masing-masing individu? Dapatkah pengalaman pribadi dianggap sebagai kebenaran hakiki?

Pertanyaan-pertanyaan di atas merupakan hakekat kehidupan manusia yang ingin hidup dalam sebuah kata kebenaran. Wal hasil, semua manusia ingin mendapatkan kebenaran dengan usahanya sendiri-sendiri. Pro dan kontra dalam mendefinisikan kebenaran sebuah obyek seringkali terjadi, sehingga masing-masing ingin berada dalam koridor kebenaran yang diyakininya. Justru dengan pro kontra akan menambah referensi dan khazanah keilmuan, sehingga akan memberikan makna positif bagi kehidupan manusia Salah seorang yang selalu menginginkan kebenaran adalah Rene Descartes (1596-1650 M). Dia adalah seorang tokoh Rasionalisme yangsangat menentang keras sebuah ide beberapa tokoh yang menyatakanbahwa pengalaman indrawi adalah sumber hakiki pegetahuan manusia. Beberapa tokoh yang ditentangnya, antara lain;Francis Bacon (1210-1292 M), Thomas Hobbes (1588-1679 M). Dalam pemikiran Descartes, akalmerupakan satu-satunya dasar atau alat memperoleh pengetahuan (Bagus, 2000: 929).

Pemikiran Descartes ini memberikan informasi bahwa keberadaan akal dalam pencarian kebenaran merupakan hal penting yang perlu untuk diungkap. Dalam bahasa agama, mungkin ini terkait dengan "kesyukuran" atas nikmat terbesar Allah berupa akal.Selain pemikiran diatas, dirinya dianggap sebagai bapak filsafatmodern, dan pencetus rasionalisme kontinental (Yusuf, 2002: 16). Ide terkenalnya adalah cogito ergo sum (aku berfikir, maka aku ada). Melalui ide itupula, dirinya ingin menegaskan bahwa hanya akal atau rasio yang dapatmenjadi satu-satunya dasar yang dapat dipercaya, dan bukan imanatau wahyu sebagaimana dipegangi oleh filosuf abad pertengahan (Keraf, 2001: 47).

Pertautan Descartes dengan akal sebagai alat pencari kebenaran, disamping perseteruan dengan beberapa filosuf pada zamannya, menjadikannya sebagai filosuf terkenal. Dengan kenyataan bahwa ideide Descartes merupakan sesuatu yang 
menarik dan penting untuk dikaji, maka makalah ini berusaha mengungkap halhal yang terkait dengan sosok filosuf ini. Sandaran pemikiran Descartes dijadikan sebagai starting point untuk kemudian melihat kontribusi pemikirannya dalam pengembangan ilmu dakwah. Ilmu dakwah dijadikan sebagai obyek pembanding dalam kerangka pemikiran Descartes, sehingga akannampak kontribusi pemikirannya dalam hal ini.

\section{B. METODE PENELITIAN}

Penelitian ini merupakan penelitian kepustakaan (library research), artinya pengumpulan data yang dilakukan dengan bersumber dari buku-buku dan dokumentasi, yaitu metode yang digunakan untuk mendapat data berupa dokumentasi atau barang tertulis, mencari data mengenai hal-hal atau variable yang berupa catatan, transkip, buku, surat kabar, majalah, agenda dan sebagainya (Suryabrata, 1998: 149).

Adapun analisis data dalam penelitian ini adalah menggunakan metode hermeneutik: merupakan langkah untuk mengetahui makna yang diharapkan, dengan cara mencari akar maksud secara kontekstual. Metode hermeneutik diartikan sebagaiprosesmengubahsesuatuatausituasi tidak tahu menjadi mengerti (Sumaryono, 1999: 24). Jadi metode hermenutik yaitu cara untuk penafsiran pemikiran Rene Descartes, untuk menangkap arti dan nuansa yang dimaksud oleh Rene Descartes secara khusus, agar peneliti dapat memahami pemikiran dari Rene Descartes tersebut, mulai dari latar belakang, karya-karyanya, dan pemikirannya secara khas.

\section{HASIL DAN PEMBAHASAN}

\section{Profil Rene Descartes}

Pembahasan tentang Descartes diawali dari tanggal lahir dan tempat kelahiranya. Ia dilahirkan di La Haye Totiraine,sebuah daerah kecil di Perancis bagian tengah pada tanggal 31 Maret 1596 dari keluarga yang mempunyai tanah yang luas (borjuis). Riwayat kuliahnya di Universitas Jesuites di La Fleche dari tahun 1604-1612 M, yang tampaknya telah memberikannya dasar-dasar keilmuan matematikamodern. Perjalanankehidupan Descrates tidakcukup hanya dengan pengetahuan matematika yang membuatnya puas, sehingga akhirnya pada tahun 1612, dia pergi ke Paris, disebuah daerah terpencil (Fauborg St. Germain) untuk belajar Geometri.

Hal aneh yang dilakukan oleh Descartes adalah, bahwa dirinya menginginkan kehidupan sendiri, tanpa hiruk pikuk duniawi. Dalam kehidupan ini biasa seperti yang dilakukan oleh pertapa untuk meningkatkan keilmuan yang dimilikinya. Ketika koleganya mengetahui keberadaannya, justru dirinya pada tahun 1617 malah mendaftar sebagai tentara Bavaria (Russell, 2007: 733). Dari sini kemudian sejarah hidupnya dihabiskan di Swedia sebagai guru yang mengajarkan pembelajaran matematika dan geometri serta filsafat. Kegiatan ini dilakukannya sampai meninggal dunia, pada tanggal 11 Februari 1650 di usia 53 tahun, dan dirinya belum sempat menikah. Dari Swedia Jenazah Descartes dipindahkan ke Prancis pada 1667, dantengkoraknya disimpan di Museum d'Historie Naturelle, Paris (Zubaedi, 2007: 18). 


\section{Kebenaran Menurut Rene Descartes}

1. Sumber dan Hakikat Pengetahuan

Menurut Descartes bahwa kebenaran tertinggi berada pada akal budimanusia. Ketika akal menjadi kebenaran tertinggi, berarti eksistensi manusia terletak pada upaya maksimalisasi akalnya. Dengan tingginya akal, maka rasio merupakan sumber pengetahuan. Ketika akal mampu menjadi sebuah pengetahuan, maka disitulah terletak sebuah kebenaran. Imbas dari pengidolaan akal sebagai alat penggalian kebenaran, Descartes tidak mempercayai sesuatu yang berasal dari luar akal dan rasio. Kebenaran harus dicari dan didasarkan denganmenggunakan kriteria "clearly and distinctly" (jelas dan terpilah) (Hunnex, 2004: 36).

Selain itu, untuk melengkapi peran akal dalam penggalian kebenaran, dirinya mengemukakan tentang adanya tiga ideide bawaan (innate ideas)manusia antara lain:

a. Ide pemikiran: ide yang memungkinkan diri sendiri sebagai makhlukyang berpikir (pemikiran adalah keberadaan manusia sendiri).

b. IdeTuhan sebagai wujud sempurna, karena manusia mempunyai ideayang sempurna, maka pasti ada sesuatu yang lebih sempurna itu. Wujudyang sempurna itu adalah Tuhan.

c. Ide keluasan: yang memungkinkan saya (kita) mengerti materi(bendabenda, objek-objek) sebagai keluasan, sebagaimana hal itudapat dipelajari secara kuantitatif (seperti ilmu ukur/ matematika) (Yusuf, 2002: 13).

Pembagian ide ini merupakan kontrol yang diberikan oleh Descartes, dalam mengendalikan peran akal bagi manusia. Dengan kontrol tersebt paling tidak ada perbedaan antara dimensi pengetahuan dan keimanan. Dengan kebenaran ide pada akhirnya menjadikan akal yang dalam bahasa Descartes disebut sebagai Ideas Claires el Distinctes (pikiran yang terang benderang dan terpilah-pilah) (Hakim, 2008: 247).

Kejelasan akal budi atau rasio ini kemudian berdampak pada minimnya peran indera lain yang dimiliki manusia. Bahkan unsur-unsur dogmatis yang seringkali "kontraproduktif" dengan akal dianggap sebagai sesuatu yang tidak dapat dipertanggungjawabkan. Descartes menunjukkan pengalaman mimpi yang tampak sangat nyata, bahkan ketika kita melakukan sesuatu yang tidak dapat dilakukan ketika dalam keadaan sadar (seperti terbang), hal itu nampak bahwa dirinya dapat melakukan. Karena itulah, tidak ada sesuatu apapun yangdapat meyakinkan kita bahwa dirinya tidak sedang bermimpi saat ini. Dan jika manusia tidak bisa yakin bahwa dirinya tidak sedang bermimpi, maka pengetahuan tidak dapat diperoleh dari proses ini (Schick, 2013: 490).

2. Metode Keraguan Rene Descartes

Sebagaimana telah di sebutkan di atas, bahwa tahapan awal dalam penggalian kebenaran dilakukan Descartes melalui keraguan yang dimunculkan dalam dirinya. Berawal dari keinginan untuk menemukan metode yangampuh dalam mencari kepastian hakiki danilmu pengetahuan, Descartes membangun suatu fondasi dasar dalam pencarian kebenaran tersebutyang biasa disebut sebagai "Metode Keraguan". Definisi metode keraguan menurut Sakban 
Rosidi (2002: 39);

"Metode keraguan dimulai dari meragukan segala sesuatu. Berpikir adalah meragukan segala sesuatu. Pada prinsip-prinsippengetahuan manusia, Descartes menegaskan: Pertama, bahwa untuk mencarikebenaran, perlu sekali dalam perjalanan hidup kita untuk meragukan. Sebagai sejauh mungkin, dari semua hal. Kedua , bahwa kami juga seharusnya mempertimbangkan sebagai palsu semua yang diragukan."

Definisi ini terlihat betapa keraguan terhadap sesuatu akan memunculkan ide bagi seseorang dalam pencarian "solusi" terhadapnya. Dengan keraguan tersebut diharapkan manusia mampu mendapatkan hal yang diinginkannya. Metode ini sebenarnya merupakan asumsi yang berawal dari kesalahan manusia dalam mendeskripsikan sesuatu. Sebagai contoh argumentasi yang menguatkan hal ini adalah statemen Descartes yang digambarkan sebagai berikut:

"Wajar bagi setiap orang untuk menerima kesimpulan yang keliru sebagai akibat penerimaan panca indra, seseorang dapat memperhatikan suatu bentuk barang di kejauhan, tetapi bentuk itu berubah sama sekalijika ia dilihat dari dekat. Padawaktu seseorang sedang mendayung perahu, ia melihat bahwa dayung yang terletak di bawahpermukaan air dalam keadaan patah. Peristiwa-peristiwa seperti itu selalu dapat terjadi dalamkehidupan lain, maka menarik kesimpulan dari peristiwa demikian memerlukan sikap yanghati-hati untuk tidak menerima pengertian yang keliru" (Bawenga, 1983: 48).

Selain ketidakpercayaan Descartes terhadap panca indera, terdapat statemen lain yang diungkap untuk mengungkap persoalan ini. berikut ungkapan lain Descartes (1993: 63):

"Saya kira bahwa segala sesuatu yang saya lihat adalah palsu. Saya percaya bahwa tidak adamemori menipu saya mewakili pernah ada. Saya tidak memiliki rasaterserah. Tubuh, bentuk, ekstensi, gerakan, dan tempat semuachimera. Apa yang kemudian akan menjadi kenyataan ? Mungkin hanya satu fakta bahwatidak ada yang pasti ".

Keraguan Descartes tampaknya bisa dipahami, mengingat bahwa kehidupan ini penuh dengan fatamorgana. Segala sesuatu dapat menipu dan membelokkan seseorang dari kebenaran yang sebenarnya. Baginya, eksistensi Tuhan saja yang dapat menjamin kebenaran tersebut (Yusuf, 2002: 14). Pendapat ini merupakan upaya ontologis yang dilakukan atas kebenaran wahyu. Begitu Descartesmembuktikan adanya eksistensi Tuhan, maka dirinya merasa memiliki dasar untuk mengakui bahwa adanya tubuh dan indera manusia berbeda dengan rasio (Hakim, 2008: 256).

Perbedaan akal dan tubuh ini mengindikasikan masing-masing mempunyai nilai dan kemanfaatan. Namun tidak dapat disamakan peran diantara keduanya. Terkait dengan peran akal dalam mencarikebenaran, Descartesmenempatkan peran rasio, intuisi dan penalaran deduktif sebagai upaya penggalian ini (Yusuf, 2002: 10).Penalaran deduktif adalah proses penalaran yang bertolak dari generalisasi (hal yang umum)lalu dirumuskan pada kesimpulan yang lebih khusus. Cara kerja ilmu-ilmu apriori (ilmupasti: matematika, logika) berdasarkan cara kerja deduktif. Pada deduksi, penalaran bertolakdari premis yang lebih luas (general) lalu ditarik 
kesimpulan yang lebih sempit.

Descartes untuk melancarkan pelaksanaan deduktif, mengajukan beberapa prinsip metodologis yangdapat menjadi landasan dalam berpikir. Beberapa tahapan dalam melakukan pencarian kebenaran ini adalah;

a. Tidak menerima apapun sebagai hal yang benar, kecuali kalaudiyakini sendiri bahwa itu memang benar, sehingga tidak ada suatu keraguan apapun yang mampu merobohkannya.

b. Memilah-milahmasalahmenjadibagianbagian terkecil untukmempermudah penyelesaian.

c. Berpikir runtut dengan mulai dari hal yang sederhana, sedikit demisedikit untuk sampai ke hal yang paling rumit.

d. Perincianyanglengkapdan pemeriksaan menyeluruh diperlukan,supaya tidak ada yang terlupakan (Ediyono, 2014: 68).

Berikut adalah peta gambar metode keraguan Descartes:

\section{METODE CARTESIAN \\ PRINSIP PERTAMA}

(Dengan intuisi, misalnya "saya berpikir, maka saya ada") (Hunnex, 2004: 105).

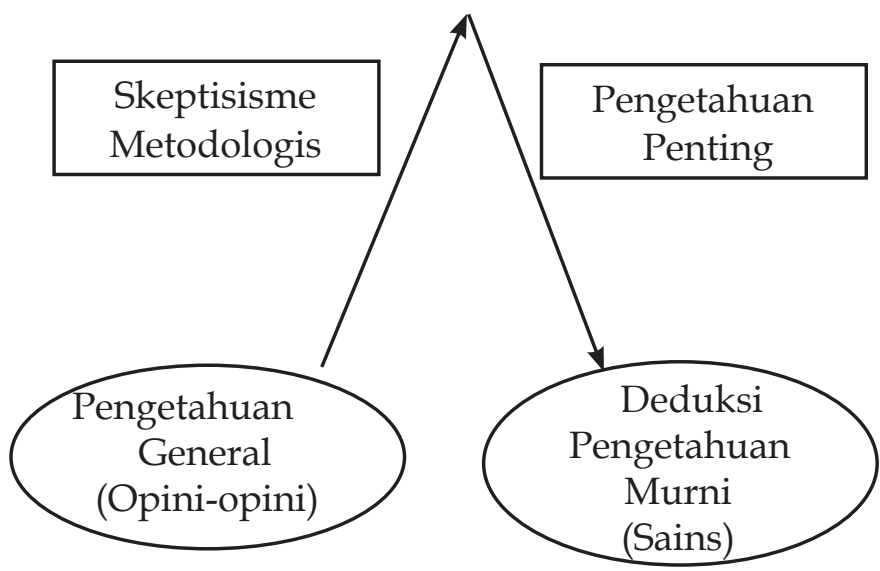

116 | Jurnal An-Nida, Vol. 11, No. 2, Juli-Desember 2019
3. Teori Kebenaran Pengetahuan

Pengambilan teori kebenaran akan menggambarkan pemikiran orang yang menganutnya. Gambaran tentang pemikirannya membersitkan "madzhab" teori tersebut. Teori kebenaran pengetahuan yang dianut oleh Descartesdan para kaum rasionalis adalah teori konsistensi atau koherensi (the consistence theory of the truth, the accordance theory of truth). Teori konsistensi atau koherensi didefinisikan sebagai suatu proposisi atau makna pernyataan dari suatu pengetahuan bernilai benar bila proposisi itu mempunyai hubungan dengan ideide dari proposisi yang terdahulu bernilai benar (Tim Dosen Filsafat Ilmu UGM, 2003: 140).

Pernyataan tersebut mengedepankan pada konsistensi hubungan antara satu proposisi dengan proposisi lainnya. Kenyataan terdahulu menjadi sebuah ukuran untuk menilai sebuah kebenaran. Sesuatu dikatakan benar adanya, apabila memang tidak lepas dari kenyataan pendahulunya. Contoh dari kebenaran koherensi adalah terkait dengan hari sumpah pemuda. Bangsa Indonesia memperingati hari Sumpah Pemuda setiap tanggal 28 Oktober. Untuk membuktikan kebenaran hari tersebut, dapat memang tidak dapat langsung melalui kenyataan dalam objektifnya, karena kenyataan hal tersebut telah berlangsung lama.

Berdasar pada kenyataan bahwa kejadian tersebut terjadi pada tanggal 28 Oktober tahun 1928, maka pembuktian dapat dilakukan. Kebutuhan mengungkap kebenaran dapat melalui ungkapanungkapan tentang fakta itu, yaitu melalui sejarah atau dapat diafirmasikan kepada

ISSN : 2085-3521, E-ISSN : 2548-9054 
orang-orang yang mengalami dan mengetahui kejadian itu. Dengan demikian, kebenaran dari pengetahuan itu dapat diuji melalui kejadian-kejadian sejarah, atau juga pembuktian proposisi itu melalui hubungan logis jika pernyataan yang hendak dibuktikan kebenarannya berkaitan dengan pernyataan-pernyataan logis atau matematis benar (Tim Dosen Filsafat Ilmu UGM, 2003: 140).

Teori kebenaran yang dianut Descartes ini mengilustrasikan tentang pentingnya afirmasi dan konfirmasi terhadap sebuah fakta. Sesuatu dikatakan benar apabila memang benar adanya. Sebaliknya, sesuatu dikatakan salah apabila tidak dapat dibuktikan baik secara nyata (riil), maupun berdasarkan rumus baku yang telah ada. Dengan demikian, untuk mengungkap kebenaran, dipersyaratkan akan kandungan fakta yang memang betul-betul dapat diterima dan terjadi sebelumnya.

4. Permasalahan Subjektivisme dan Solusi Descartes

Subyektifitas pemikiran manusia akan dipengaruhi oleh pengalaman yang dimilikinya. Sesuatu akan dinilai sama antara satu orang dengan lainnya apabila mereka terlibat dan menyaksikan sebuah kejadian atau pembuktian dengan hasil yang sama pula. Subyektifitas ini yang kemudian justru melahirkan pemikiranpemikiran dan pengetahuan baru di kancah ilmu pengetahuan. Dengan subyektifitas akan mengembangkan pemikiran disatu sisi, namun akan menyempitkan pola pikir manusia.

Pemikiran Descartes tentang cogito ergo sum memberikan suatu kenyataan yang kuat, bahwa sesuatu akan dinilai eksis apabila secara subyektif dinyatakan ada. Namun disisi lainnya, pemikiran ini justru dipandang sebagai kenyataan memiskinkankadar kepastian. Sebab subjek yang dinyatakan Descartes di dalam cogito adalah subjek yang benar-benar privat dan terisolasi. Pada tahapini, Descartes meyakini mengenai eksistensi dirinya sendiri saja, sebagaipengada berpikir, tidak lebih dan tak ada yang lain. Namun di sini, yang muncul adalah persoalan subjektivisme.

Hal ini sangat esensial, karena membawa akan membawa pada sebuah pertanyaan lanjutan, seperti; jikasemua dari kesadaran manusia pada awalnya mempunyai nilai eksklusif dari suatu keadaan subjektif dari jiwa individual (peristiwa subjektif murni), bagaimana seseorang mengetahui kodrat sesuatu di luar dirinya?. Pertanyaan lain bagaimana seseorang sampai padakesadaran yang berbeda dengan orang lain?.

Descartes dalam menjawab kedua pertanyaan di atas, menempuh dua jalan:kodrat dari pengada sempurna dan kodrat dari pengalaman indrawisaya (Gallagher, 1994: 38). Pertama, Dirinya menyatakan bahwa pengalaman indrawi dirinya bukanlah ciptaan sadar sendiri. Sebaliknya, data yang muncul di dalam persepsinya sering dipaksakan padanya, padahal hakikatnya berlawanan dengan kehendak dan keinginannya sendiri. Untuk menguatkan perspektifnya, Descartes mencontohkan bahwa dirinya tidak akan mungkin menyatakan bahwa "bajaitu keras dan tidak enak" sebelum membuktikan bahwa baja itu secara kodrati memang keras. Dirinya menambahkan bahwa asumsinya tersebut dimunculkan 
karena dirinya bukanlah pencipta atau penyebab munculnya ide itu. Dengan demikian, data yang diungkapkannya mempunyaieksistensi sendiri yang bukan atas dasar asumsinya.

Kedua, Descartes tidak percaya penyebab kerasnya baja tersebut adalah Allah (pencipta), karena itu tidak sesuai dengan kodrat Allah sebagai pengada sempurna yang tidakmungkin menjadi sebab penipuan. Oleh sebab itu, Descartes meyakinipengalaman yang dimilikinya mengenai benda-benda, merupakanpemaksaan oleh bendabenda itu sendiri. Maka, hanya sifat-sifat yangdengan jelas dan disting terdapat di dalam benda-bendalah yangdianggap pasti sebagai yang real secara objektif. Itulah yang disebut"keluasan" dan "gerakan", atau dengan kata lain bahwa "esensi daribudi adalah pikiran dan esensi dari material adalah keluasan" (Gallagher, 38-40).

\section{Relevansi Pemikiran Rene Descartes dengan Ilmu Dakwah}

Konsep dan pemikiran Descartes lebih diarahkan pada pentingnya akal atau rasio dalam mencari kebenaran. Akal dimaksimalkan perannya dengan cara deduktif untuk mendapatkan ilmu "baru". Konsepsi ini dipandang sebagai keilmuan eksakta dan diarahkan pada pemenuhan kebutuhan akan pengetahuan tersebut. Dari sisi ini dapat ditarik benang merah bahwa upaya memaksimalkan akal lebih diarahkan pada penemuan teori baru yang dapat digenaralisir untuk diterapkan dimana dan kapan saja, tidak terfokus pada satu kejadian semata. Fenomena masyarakat yang didekati dengan inderawi belum menjadikannya sebagai sebuah pengetahuan yang pasti kebenarannya. Elaborasi ini hakekatnya penulis arahkan untuk menyatakan bahwa pemikiran deduktif sangat berbeda dengan induktif, dimana perbedaan yang ada tidak hanya dari segi proses, namun juga hasilnya. Persoalannya kemudian adalah bagaimana menarik sebuah pertautan antara logika deduktif dan induktif?

Kedua logika berfikir ini apabila dilihat dari segi filsafat lebih diasumsikan sebagai penyelidikan terhadap pengetahuan dan cara memperolehnya. Hal ini dalam kajian filsafat lebih disandarkan pada kajian filsafat ilmu yang merupakan bagian dari filsafat itu sendiri. Filsafat ilmu didefinisikan sebagai hasil perpaduan antara proses berfikir filsafat dan pengetahuan umum (Masykuri, 1985: 138). Oleh karena itu filsafat ilmu lebih dekat dengan hakekat pengetahuan dan cara berfikir yang digunakan untuk mendapatkan hasil pemikiran yang absolut (Muammar, 2012: 20). Dengan demikian logika deduktif dan induktif merupakan alur pikir atau cara, sehingga perbedaannya terletak pada sisi pencapaian tujuan.

Dengan logika pikir ini kemudian akan memunculkan hasil yang berbeda antara satu dengan lainnya. Logika pikir ini yang kemudian diyakini sebagai akar masalah perbedaan persepsi antar filosuf dan ilmuan dalam menghasilkan temuannya. Persoalannya kemudian adalah bagaimana relevansi pemikiran Descartes dan ilmu dakwah? Mungkinkah konsepsi pemikiran antara keduanya dapat dipertemukan atau bahkan dipersatukan dalam menggali kebenaran hakiki atau absolut? 
Mengulas paparan di atas, diketahui bahwa filsafat rasionalisme Descartes menekankan bahwa pada hakikatnya sumber pengetahuan sejati adalah akal budi atau rasio, bukan pengalaman. Pengalaman hanya dapat dipakai untuk menegaskan pengetahuan yangtelah didapatkan dari rasio (Petrus, 2004: 205). Bagi Descartes, manusia harus menjadi titikberangkat dari pemikiran yang rasional demi mencapai kebenaran yangpasti. Untuk itu, rasio harus berperan semaksimal mungkin (Rapar, 1996: 112).Dari sisi ini jelas bahwa ide rasionalitas lebih ditekankan pada aspek epistemologi pemikiran filsafat versi Descartes. Lantas bagaimana epistemologi yang dikembangkan ilmu dakwah?

Dakwah merupakan perintah Allah SWT yang dalam kacamata ini mempunyai nilai transenden dan tidak dapat didekati dengan rasio semata. Keberadaan perintah berdakwah yang termaktub dalam QS. An Nahl: 125, "Serulah (manusia) kepada jalan Tuhan-mu dengan hikmah dan pelajaran yang baik dan bantahlah mereka dengan cara yang baik. Sesungguhnya Tuhanmu Dialah yang lebih mengetahui tentang siapa yang tersesat dari jalan-Nya dan Dialah yang lebih mengetahui orang-orang yang mendapat petunjuk".Ayat ini merupakan perintah Tuhan kepada umatnya. Dalam kacamata keilmuan, perintah dakwah tidak dapat dirasionalisasi, dikarenakan hal ini merupakan dimensi esoterik, bukan eksoterik (Muammar, 2012: 5). hal ini lebih terkait dengan keimanan, bukan keilmuan. Lantas bagaimana dengan ilmu dakwah?

Ilmu dakwah adalah bagian dari kajian keIslaman yang diarahkan pada dimensi eksoterik. Dalam scope ini jelas bahwa keberadaannya dekat dengan pemikiran Descartes tersebut. Sisi rasionalitas ilmu dakwah didekati dengan pemikiran Descartes untuk menggali kebenaran dalam berbagai hal. Sekilas jelas keduanya mempunyai relevansi yang sama sebagai sebuah kerangka penggalian kebenaran. Namun, capaian dari keduanya mempunyai perbedaan yang mendasar, dari sisi kerangka berfikir (deduktif dan induktif) maupun fokus keilmuan (eksakta dan sosial).

Berbicara relevansi pemikiran Descartes dalam Ilmu Dakwah tidak dapat dilepaskan dari dinamika sejarah, dimana kaum muslim menjadi konsumen produk yang dihasilkan oleh orang di luar muslim (Barat). Realitas yang ada orang muslim masih melakukan adopsi pemikiran Barat dalam berbagai kehidupan keilmuan maupun budaya, yang pada akhirnya mengantarkan terminologi hegemoni Barat terhadap umat Islam sangat kelihatan. Dari sini akhirnya warna keilmuan juga diukur menggunakan standar filosuf-filosuf Barat, yang diyakini mempunyai relevansi dalam pencarian kebenaran.

Membongkar sebuah dinamika pemikiran, berarti secara tidak sengaja juga tidak akan lepas dari diterminan historisnya. Secara garis besar determinan yang melingkupi tradisi keilmuan Islam dapat dipilah menjadi dua bagian besar, yaitu bangsa Arab dan bangsa-bangsa yang ditaklukkan oleh bangsa Arab. Diterminasi itu mempunyai dampak yang cukup besar pada perkembangan tradisi yang mengalir di lingkungan umat muslim. Misalnya, beberapa kalangan sulit untuk membedakan antara Islam dan Arab itu sendiri, hal yang 
demikian dipicu dengan gerakan Arabisasi (at-Ta'rib) yang dikonversi pada tubuh Islam itu sendiri (Majid, 2008: 28).

Bermula dari gerakan $A t-T a^{\prime}$ rib inilah bermula transformasi tradisi secara brutal pada bangsa-bangsa non Arab, kemudian pada titik klimaksnya menjadi sebuah problem yang melilit kaum muslim dalam hal dinamika keilmuan. Determinasi tersebut merembes pada taradisi keilmuan Islam yang termanifestasikan dalam bentuk pewarisan tradisi kuno (al-mauruts alqadim) secara mentah tanpa diikuti oleh sikap kritis. Realitas keilmuan Islam pun bagaikan telur di ujung tanduk atau berada pada taraf kestatisan (harakat I'tmad)(Arif, 2008: 29).

Fenomena tersebut di atas jika diseret pada realiitas kekinian maka akan muncul anomali-anomali pada tradisi keilmuan Islam. Dianggap kurang nomal karena, yang dominan pada tradisi keilmuan keislaman hanya pada satu epistemologi saja, yaitu yaitu epistemologi bayani. Hal ini sebagai akibat Arabisasi tadi yang terlalu dipaksakan sebagai bagian dari tubuh Islam itu sendiri.

MenurutHasanHanafi,keilmuanIslam sebagai warisan intelektual yang sampai kepada umat saat ini dapat diklasifikasikan menjadi tiga macam, yaitukeilmuan naqli murni, naqli-'aqli dan 'aqli murni. Namun pada kenyataannya yang merembes dan menjadi kesadaran pada diri umat muslim hanya didominasi oleh keilmuan yang naqli murni saja. Sedangkan yang 'aqli murni tersisihkan oleh ilmu-ilmu keagamaan. Gejala ini sangat berkaiatan dengan bergesernya kecenderungan umat dari ilmu filsafat, bahkan diangapnya sebagai bagian dari ilmu-ilmu asing (Arif, 2008: 124).

Sebagai contoh akibat riil dari fenomena di atas adalah, keberadaan Islam yang sangat terbelakang di penghujung peradaban dunia. Di antara Negara-negara Muslim dunia, belum satu pun yang dapat dikategorikan ke dalam Negara industri, paling banter disebut sebagai Negara yang sedang membangun (developing countries)(Raharjo, 2007: 23). Menunjukkan bahwa, dalam produktifitas konkret, keberadaan muslim masih sangat jauh dari perkembangan Barat yang tak terjangkau.

Selanjutnya, kembali pada perbincangan mengenai ilmu dakwah, kemandegannya sangat tergantung pada epistemologi yang digunakan dalam memahami wahyu Tuhan. Walaupun di keilmuan Islam, termasuk ilmu dakwah skema konstruk epistemologi telah disandarkan pada pendapat al-Jabiri (bayani, burhani dan 'irfani (al-Jabiri, 1989: 53). Penjelasan konkret epistemologi ilmu dakwah akan dijabarkan sebagai upaya melihat relevansinya dengan pemikiran Descartes.

Pertama, Melalui epistemologi bayani (explanatory), yang dilihat secara terminologis berarti pola pikir yang bersumber pada nash, ijma', dan ijtihad (al-Jabiri, 1993: 383-384). Dalam paradigma ini, epistemologi bayani merupakan studi filosofis terhadap struktur pengetahuan yang menempatkan teks (wahyu) sebagai suatu kebenaran mutlak. Sedangkan akal hanya menempati tingkat kedua dan sifatnya menjelaskan teks yang dimaksud. Tradisi bayani muncul tidak terlepas dari tradisi teks yang berkembang dalam ajaran Islam, dan setidaknya ada 50 ayat $\mathrm{Al}$ 
Qur'an yang mengungkap kata bayani ini (Mahmasam, 1961: 165-169).

Penjelasan ini memberikan makna bahwa ilmu dakwah sangat berbeda dengan kegiatan dakwah. Operasional dakwah Islam bersumber pada teks atau nash al Quran sebagai sumber utamanya. Sedangkan struktur keilmuan dakwah juga bersumber dari al Quran, namun pengembangannya lebih ditekankan pada pemikiran rasionalitas, dimana upaya singkronisasi menjadi sebuah kebutuhan atau prasyarat dalam metode ilmiah dengan berbagai treatment di dalamnya. Dengan demikian, maka epistemologi bayani merupakan bentuk dari sumber pengetahuan ilmu dakwah itu sendiri.

Kedua, Melalui epistemologi 'irfani, yang secara etimologis, berarti al-ma rifah, al-'ilm, al-hikmah (al-Jabiri, 1993: 251). Epistemo $\neg$ logi irfani secara eksistensial berpangkal pada zauq, qalb, atau intuisi yang merupakan perluasan dari pandangan illuminasi, dan yang berakar pada tradisi Hermes. Aturan normatif dalam 'irfan praktis seperti dalam rumusan $\urcorner$ rumusan tentang perjalanan spiritual melalui beberapa tahapan. Pada dataran ini, dalam hubungannya dengan dakwah Islam tidak begitu banyak berpengaruh terhadap sumber pengetahuannya, mengingat dakwah pada dasar $\neg$ nya lebih kepada persoalan perubahan sosial dan transformasi nilai-nilai Islam yang konkret dan rasional.

Ketiga, Melalui epistemologi burhani, yang lazim diartikan sebagai argumentasi yang jelas. Sedangkan menurut istilah $\neg$ nya (logika) berarti aktifitas intelektual untuk menetap $\neg$ kan kebenaran proposisi dengan metode deduktif, yakni dengan cara mengaitkan proposisi satu dengan proposisi lainnya yang bersifat aksiomatik atau setiap aktifitas intelektual untuk menetapkan kebenaran suatu proposisi (alJabiri, 1993: 383-385). Melalui epistemologi Burhani membangun pengetahuan dan visinya atas dasar potensi bawaan manusia, yakni kemampuan melakukan proses penginderaan, eksperimentasi, atau konseptualisasi.

Metodeini pertamakalidikembangkan di Yunani melalui proses panjang dan puncaknya pada masa Aristoteles. Metode ini, biasa disebut Aristoteles dengan sebutan analisis, yaitu menguraikan ilmu atas dasar prinsip-prinsipnya. Nampaknya, epistemologi burhani inilah yang lebih kental dengan sumber dakwah Islam setelah epistemologi bayani (teks/nash).

Ketiga bentuk epistemologi "versi Islam" tersebut di atas, merupakan bagian dari terapan ilmu dakwah di tengah kancah keilmuan. Karakteristik ini pada awal pemunculan sampai dengan perkembangannya melalui mekanisme secara runtut sejak periode klasik sampai dengan modern tergambar secara jelas dalam berbagai tipologi masyarakat Islam, baik itu bangunan keilmuan maupun aplikasinya. Lantas bagaimana relevansinya dengan pemikiran rasionalitas Descartes? Adakah titik temu diantara keduanya? Ataukah justru terjadi perbedaan?.

Sebelum penulis menjawab persoalan di atas,kiranya perlu untuk dikemukakan bahwa mengakarnya dogma di kalangan umat muslim yang menyatakan bahwa al-Quran merupakan otoritas kebenaran yang tidak bisa tersentuh (untauchable). Hal 
ini merupakan realitas dari mengakarnya kerangka naqli murni. Umat muslim terasa lupa bahwa al-Quran itu sendiri mempunyai makna yaitu, sebagai teks langit (berupa ajaran keagamaan) tapi di sisi lain merupakan teks bumi (berupa ajaran kemanusiaan) (Misrawi, 2007: 403).

Dari kenyataan bahwa umat Islam mempunyaiajaran tertinggiyang digunakan untuk mengurai persoalan, disatu sisi membersitkan makna bahwa dirinya tidak pro dengan rasionalisasi Descartes dengan kebebasan berpikir. Namun dalam konteks penggunaan akal, justru umat Islam setuju dengan pentingnya akal dalam mengurai dan mencari kebenaran sebenar-benarnya. Cogitu ergo sum sebagai salah satu kerangka pikir Descartes merupakan klausul yang sepadan untuk dilihat dalam perspektif ilmu dakwah dan ilmu keislaman lainnya.

Kenyataan kerangka pikir ini kemudian dapat dilihat mendalam dalam kaitannya dengan keilmuan dakwah yang menggunakan kontrol naqli dan relevansinya dengan pemikiran Descartes. Hakekatnya, rasionalisme Descartes teraplikasikan secara natural tradisi keilmuan Islam, termasuk ilmu dakwah. Pembuktian hal ini adalah dengan munculnya tiga komponen epistemologi dalam Islam, khususnya epistemologi burhani.

Pernyataan di atas bukan berarti memposisikan epistemologi keilmuan Islam sama dengan pemikiran Descartes. Namun untuk menyatakan bahwa rasionalisme Descartes lebih bebas untuk mengurai kebenaran, sementara epistemologi Islam masih terbatasi dengan kerangka pikir naqli. Al-Quran memberikan kebebasan

122 | Jurnal An-Nida, Vol. 11, No. 2, Juli-Desember 2019 umat Islam untuk mengeksplorasikan pemikirannya, selama tidak bertentangan dengan keberadaan al-Qur'an dan hadits sebagai sumber ajarannya. Hal ini mungkin yang dipahami para filosuf yang tidak beragamasebagaisesuatuyangmenghalangi berkembangnya pemikiran. Realitas asumsi para filosuf yang memandang bahwa agama akan menghambat kebebasan berfikir menjadikannya tidak mempercayai agama, sehingga banyak diantara mereka yang tidak beragama (atheis). Fenomena inii banyak dijumpai dalam perkembangan era kekinian.

Adapun hubungan teori kebenaran pengetahuanDescartesdenganilmudakwah jelas inheren dilihat dari metode ilmiah yang digunakan. Maksudnya, bahwa teori ini sejalan dengan cara penggalian kebenaran ilmu dakwah yang dapat dilihat dari sisi materi, metode maupun obyek kajiannya. Dalam ilmu dakwah, penggalian kebenaran disandarkan pada teori-teori sosiologis, antropologis dan keilmuan lainnya. Ini merupakan bukti bahwa aplikasi ilmu dakwah sesuai dengan preposisi yang telah ada dan prooven (terbukti kebenarannya). Seseorang yang mempelajari ilmu dakwah akan belajar sejarah dan membuktikan teoriteori dalam ilmu dakwah yang diproduksi ulama atau ilmuan masa sebelumnya. Upaya membuktikan sesuatu yang baru ini merupakan bukti kesamaan perspektif antara teori kebenaran pengetahuan dan teori-teori dalam ilmu dakwah.

\section{Simpulan}

Sebagai akhir pembahasan dapat disimpulkan bahwa proses penggalian kebenaran yang dilakukan Descartes ISSN : 2085-3521, E-ISSN : 2548-9054 
dengan mengeksplorasi akal sebagai subyek dinilai sesuatu yang luar biasa. Namun, karena penulis merupakan seorang muslim yang terbatasi dengan dalil naqli hendaknya para pengikut Descartes tetap mempertimbangkan adanya Tuhan yang menguasai jagad raya ini. Dari konsepsi ini akan memunculkan kebenaran, dimana kebenaran pasti datangnya dari Tuhan dan kebenaran eksperimental adalah wujud maksimalisasi peran akal sebagai anugerah terindah dari Tuhan.

Terkait dengan terobosan Descartes melalui tesis andalannya cogitoergo sum telah melahirkan suatu revolusipemikiran yang sangat luas dalam kancah filsafat. Dengan tegas Descartes memproklamirkan bahwa hanya akal atau rasio sajalah yang dapat menjadi satu-satunya dasar yang dapat dipercaya, dan bukan iman atau wahyu sebagaimana yang selalu dipegangi oleh abad pertengahan.Selain itu metode keraguannya, Descartes menapaki pemikiran filosofisnya dengan menyangsikan segala sesuatu dalam upaya mencapai suatu kepastian hakiki yang selalu ia rindukan. Meskipun pada akhirnya ia menyadari bahwa sesungguhnya tidak ada sesuatu yang benar, kecuali ketidakpastian itu sendiri.

Adapun revelansi pemikiran Descartes dalam persoalan cogitu ergo sum dipandang tidak inheren dengan keilmuan dakwah, yang masih terbatasi dengan kebenaran dalil naqli. Pemikiran Descartes yang dianggap relevan dengan keilmuan dakwah terletak pada teori pengetahuan yang dikembangkan, tentunya dengan menggunakan alur metodologi ilmiah. Tantangan untuk membuktikan kebenaran ajaran Islam dalam kancah ilmu dakwah merupakan sebuah keniscayaan.Wallahu ala'lam.

\section{DAFTAR PUSTAKA}

al-Jabiri, Muhammad Abed. (1989). Takwin al-aql al-Arabi. Beirut: Markaz Dirasah al-Wihdah al-Arabiyah.

-'Abid. (1993).Bunyah al'Aql al'Arabiy, (Beirut: al-Markaz al-Tsaqafl al-' Arably.

Arif, Mahmud. (2008).Pendidikan Islam Transfomatif. Yogyakarta: LKiS Pelangi Aksara.

Bagus,Lorens. (2000). Kamus Filsafat. Jakarta: PTGramedia Pustaka Utama.

Bawenga. (1983).Sebuah Studi Filsafat. Jakarta: Pradnya Paramita.

Descartes, Rene. (1993). Discourse on Method and Meditations on First Philosophy, terj., Donald A. Cress Indianapolis/ Cambridge: Hacket Publishing Company.

Ediyono,Suryo. (2014).Filsafat Ilmu. Yogyakarta: Penerbit Kaliwangi.

Gallagher,Kenneth T. (1994).Epistemologi. Yogyakarta: Kanisius.

Hakim, Abdul. Atang dan Beni Ahmad Saebani. (2008).Filsafat Umum; Dari Metologi sampai Teofilosofi. Bandung: CV Pustaka Setia.

Hunnex,Milton D. (2004).Peta Filsafat; Pendekatan Kronologis dan Tematis. Jakarta: Teraju.

Keraf, A. Sonny. (2001).Ilmu Pengetahuan; Sebuah Tinjauan Filosofis. Yogyakarta: Kanisius. 
Mahmasam,Subhi. (1961).Falsafatu atTasyri'fi al-Islam. Beirut: Dar al-'Ilml al Malayin.

Majid, Abd. Mun'im. (2008).“Tarikh alHadharah al-Islamiyah fi al-Ushur al-Wustha" dalam Pendidikan Islam Transfomatif. Yogyakarta: LKiS Pelangi Aksara.

Masykuri, Imam. (1985).Filsafat Ilmu, Sebuah Dasar Bagi Pemahaman dan Pengembangan Ilmu. Jakarta: Jurnal Imu Budaya.

Misrawi, Zuhairi. (2007). “Wawasan baru Islam: Kado Peikiran untuk Mas Dawa". dalam Demi Toleransi Demi Pularisme. Jakarta: Paramadina.

Muammar,M.Arfan, Abdul Wahid Hasan. (2012).Studi Islam, Perspektif Insider atau Outsider. Yogyakarta: IRCiSoD.

Petrus, Tjahjadi,Simon. L. (2004). Petualangan Intelektual; Konfrontasi Para Filsuf dari Zaman Yunani Hingga Zaman Modern. Yogyakarta:Kanisius.

Rahardjo, Dawam. (2007). Krisis Pradaban Islam" dalam, Bayang-bayang Fanatisisme. Jakarta: Pusat Studi Islam dan Kenegaraan Universitas Paramadina.

Rapar,Jan Hendrik. (1996).Pengantar Filsafat. Yogyakarta:Kanisius.

Rosidi, Sakban. (2002). The History of Modern Thought; A Brief but Critical Reminder. Malang: CISC.

Russell, Bertrand. (2007). Sejarah Filsafat Barat: Kaitannya dengan Kondisi SosioPolitik Zaman Kuno Hingga Sekarang. Yogyakarta: Pustaka Pelajar.

Schick, Theodore, Jr, Lewis Vaughn. (2013). Doing Philosophy; An Introduction Through. New York : McGraw-Hill.
Sumaryono. (1999). Hermeneutik Sebuah Metode Filsafat. Yogyakarta: Kanisius.

Suryabrata, Sumadi. (1998). Metodologi Penelitian. Jakarta: Raja Grafindo.

Tim Dosen Filsafat Ilmu UGM. (2003).Filsafat Ilmu; Sebagai Dasar Pengembangan Ilmu Pengetahuan. Yogyakarta: Liberty.

Yusuf, Akhyar. (2002). Pengertian Epistemologi, Logika, Metodologi, Ontologi, dan Aksiologi. Jakarta: Program Paska sarjana UI.

Zubaedi dkk. (2007). Filsafat Barat; Dari Logika Baru Rene Descartes Hingga Revolusi Sains ala Thomas Kuhn. Yogyakarta: Ar Ruzz Media. 